\title{
ЗНАКОМАЯ НЕЗНАКОМКА
}

Рец. на кн.: Заре Григорьевне Минц посвящается...:

Публикации, воспоминания, статьи. К 90-летию со дня рождения / Ред.-сост. Татьяна Кузовкина, Михаил Лотман, Майя Халтурина. Таллинн: Издательство ТЛУ, 20І7. 528 с. Тираж не указан.

\section{С. Н. Доценко}

(Таллинн)

Память о 3. Г. Минц - это то, что объединяет всех ее учеников. Учеников, которые учились у нее в разные годы, общались с нею (близко или не очень, долго или коротко). А еще их объединяет что-то неуловимо общее, несмотря на разность характеров, интересов, дальнейшей жизненной судьбы. В значительной мере это общее можно определить так: личность учителя, которая наложила отпечаток на его учеников. Это верно подметила С. Кульюс: «Учителя не уходят. Они живут в нас» (408). Только добавлю: наши учителя живут в нас даже тогда, когда мы этого не замечаем или не осознаем.

Рецензируемый сборник не совсем типичен, ибо из четырех его разделов («Из архива 3. Г. Минц и Ю. М. Лотмана», «3. Г. Минц в письмах», «Воспоминания», «Заре Григорьевне посвящается... Статьи и заметки») самую малую по объему часть составляет последний, как бы самый «научный» раздел (в нем всего 4 статьи). Остальные разделы - это преимущественно эпистолярные и мемуарные документы. Не в упрек авторам статей, письма и мемуары представляются более интересными. Почему? Разумеется, потому, что в них 3. Г. открывается как ученый и как человек, причем с довольно неожиданных сторон. Будучи учеником 3. Г. с 1977 г. (вначале как студент, а затем уже как аспирант-заочник), я, казалось бы, достаточно хорошо знал ее характер, и мне думалось, что ничего в моем понимании личности 3. Г. публикуемые в сборнике тексты не изменят. Однако мемуары друзей и коллег 
все равно добавляют к этому запомнившемуся образу новые черты и нюансы. Правда, даже новое на поверку оказывается вполне знакомым и понятным. Вот, например, в воспоминаниях В. Паперного «Эскизы к портрету Зары Григорьевны» находим такой эскиз («Чтение лекции с бумажкой»): «<...> Начиная лекцию, Зара Григорьевна обыкновенно доставала чистый лист белой бумаги, с которым она начинала производить постоянно одни и те же манипуляции. Сначала она складывала этот лист вдвое, потом еще раз вдвое, потом складывала его таким же образом еще несколько раз. После этого она расправляла лист, а затем снова многократно складывала, расправляла и опять складывала. Следующим этапом этой магически-мнемонической процедуры было разрывание листа по образовавшимся сгибам. В конце концов от листа оставались маленькие аккуратные прямоугольные кусочки, которые затем сминались и превращались в шарики. Шарики сначала оставались на столе, а потом Зара Григорьевна их тщательно собирала, и они куда-то бесследно исчезали» (395-396). Прочитав эскиз В. Паперного, долго я пытался вспомнить об этом впечатлении от лекций 3. Г. - и с недоумением пришел к выводу, что такого решительно не помню. Как-то не запечатлелось. Усомниться в достоверности мемуариста нет никаких оснований, да и после недолгого размышления понимаешь: все описанное было вполне в стиле 3. Г. Только добавлю, что мне почему-то на долгие годы запомнился голос 3. Г., его звучание, тембр, интонация, ритм речи.

Разбирать точность и достоверность мемуаров - дело нелегкое и не совсем благодарное, особенно когда ты сам являешься тем субъектом, который может быть таким же (или похожим) мемуаристом. Поэтому стоит лишь отметить, что разные мемуары, включенные в сборник, тяготеют к двум основным моделям (жанрам), отмеченным Ю. М. Лотманом. Это либо мемуары, ориентированные на создание «житийного» образа (при всей условности этого термина применительно к светскому человеку), либо мемуары, ориентированные на создание образа «анекдотического» (см. Лотман 1986: 106-121). Разумеется, в самом определении «анекдотический» нет ничего уничижительного: речь идет лишь 
о таком типе мемуарно-биографического описания, которое складывается преимущественно из рассказов о забавных и/или поучительных эпизодах из жизни 3. Г. К жанру «житийному» приближаются скорей воспоминания С. Кульюс («Страницы дорогих воспоминаний: Зара Григорьевна Минц») и Е. Мирецкой («И уже не так страшно!»), к жанру «анекдотическому» - скорей воспоминания В. Паперного («Эскизы к портрету Зары Григорьевны») или М. Безродного («За партой»).

Что достоверней и точней сохраняет и передает образ человека «житие» или «анекдот»? Нет однозначного ответа. Точнее говоря, оба варианта ответа будут верными: просто эти два аспекта дополняют друг друга, создавая более точный и более объективный образ человека как личности. А 3. Г. была личностью яркой, харизматичной. Что, кстати, было не так уж просто в соседстве с Ю. М. Лотманом, здесь впору было затеряться в свете его харизмы. «Житие» - более концептуально, тогда как «анекдот» по самой своей природе - более фактологичен, но и более фрагментарен. Не случайно В. Паперный, вспоминая несколько эпизодов-анекдотов из жизни 3. Г., невзначай оговаривается, называя их так: «скромные и бессвязные воспоминания» (395). Скромные - потому что не претендуют на глубину понимания, а бессвязные - потому что не претендуют на цельность и завершенность портрета. Но бесспорно одно - анекдот оказывается как-то реальней и демократичней, да и лучше показывает чисто человеческие черты характера (даже в том случае, когда анекдот становится апокрифом).

К тому же 3. Г. сама любила забавные и поучительные анекдоты. И сама рассказывала их на лекциях и семинарах. Один такой рассказанный 3. Г. анекдот вспоминает М. Безродный: «<..> Студенты ЛГУ, и она в их числе, посетили в Ясной Поляне ветхого старика, видевшего Толстого. Когда его попросили рассказать, как барин пахал, старик закричал “пылишша!" и долго кашлял от смеха, а затем объяснил: граф неправильно заглублял лемех и шел в облаке пыли. Мужики потом, конечно, все перепахивали» (406).

Видимо, этот анекдот о Л. Н. Толстом 3. Г. рассказывала неоднократно разным поколениям студентов; в 1980 г. я его лично слышал 
из уст 3. Г. в курсе, посвященном биографии и творчеству Толстого ${ }^{1}$ Другой анекдот из воспоминаний М. Безродного не имеет прямого отношения к 3. Г., но к нему тоже хочется сделать примечание.

«А впрочем, бают, у братьев Соколовых, попросивших в Заонежье исполнить им былину, сказитель, настраивая гусли звончатые на старинный лад, деловито уточнил, по Гильфердингу петь или по Рыбникову» (404).

Этот анекдот я слышал на одной из лекций Ю. М. Лотмана правда, в несколько иной версии. В бытность студентом ЛГУ (в 1946-1950 гг.) Ю. М. Лотман посещал семинар В. Я. Проппа, и тот однажды пригласил на семинар сказителя былин Петра Ивановича Рябинина-Андреева (1905-1953), правнука знаменитого сказителя Трофима Григорьевича Рябинина, чтобы тот продемонстрировал студентам, как именно пелись былины. Перед исполнием Петр Иванович Рябинин-Андреев спросил В. Я. Проппа: «Владимир Яковлевич, а как петь - по Гильфердингу или по Рыбникову?» Насколько помню, этот анекдот, рассказанный Ю. М. Лотманом, должен был свидетельствовать, что живая традиция исполнения былин к середине XX века уже вырождалась, сказители были грамотные, поэтому хорошо знали тексты былин, опубликованные в фольклорных сборниках, самые известные из которых были: «Песни, собранные П. Н. Рыбниковым. Ч. 1: Народные былины, старины и побывальщины» (М., 1861) и «Онежские былины, записанные Александром Федоровичем Гильфердингом летом 1871 года» (СПб., 1873).

\footnotetext{
1 Отголоском этого курса в осеннем семестре 1980 г. являются две фотографии, опубликованные в сборнике на стр. 220. На одной из них (верхней) 3. Г. сидит за столом, а перед нею - пустые бутылки из-под «Советского шампанского» и такие же пустые бокалы. На другой (нижней) - 3. Г. с бокалом в окружении группы студентов. Все запечатленное происходило по окончании последней лекции семестра, когда по традиции студенты отмечали окончание аудиторной эпопеи: ведь последний (весенний) семестр у филологов 5-го курса был свободный, т. е. без лекций и семинаров, и был предназначен для написания дипломной работы. Вот это-то окончание лекций мы и отмечали распитием игристого вина из специальных бокалов, на которых были выгравированы имена студентов - будущих выпускников. Как очевидно, 3. Г. с чувством юмора отнеслась к шалости студентов, которые запечатлели ее в таком неакадемическом антураже, и блестяще сыграла свою роль.
} 
Надо полагать, что биографические анекдоты о знаменитых людях известны прежде всего потому, что анекдот - это тот феномен, который лучше всего запоминается. Другое дело, что в биографиях одних лиц анекдотов много, а в биографиях других - мало.

Еще одно замечание о том, что ученики - это своеобразное продолжение своих учителей (или, если точнее, своеобразное приложение к ним). В воспоминаниях В. Перелыгина «Зара Григорьевна Минц в Пярну» находим такой эпизод: «В самом начале дружбы с Давидом Самойловым (Пярну, 1976 год, а познакомил меня с ним Виталий Белобровцев), поэт представлял меня своим московским друзьям таким образом: “Виктор Александрович. Учитель русской изящной словесности в эстонской школе”. Передо мой - те же непроницаемые лица гостей, а поэт продолжает, почти торжественно: "Ученик Юрия Михайловича Лотмана и Зары Григорьевны Минц!” Еще не прозвучали последние слова, а лица вдруг расцветают от приятных улыбок, как будто только что заметили над моей головой нежный световой ореол, нимб» (394).

Со мной произошла похожая история. В феврале 1981 г. я жил в Ленинграде, просиживая часы в рукописном отделе ГПБ им. М. Е. Салтыкова-Щедрина - работая над дипломной работой о творчестве Вяч. Иванова (научным руководителем дипломной работы была 3. Г.). Однажды моя знакомая, Нина Владимировна Ивочкина ${ }^{2}$, научный сотрудник Эрмитажа, предложила мне пойти в гости к А. А. Долининой. Поводом послужил приезд в Ленинград знаменитого лингвиста Ю. Д. Апресяна, поэтому в квартире А. А. Долининой собрался весь ленинградский лингвистический бомонд. На этом фоне моя фигура никому неизвестного студента из Тарту выглядела совершенно безликой и безымянной. Но после того, как меня представили «учеником 3. Г. Минц», мои безликость и безымянность несколько развеялись

\footnotetext{
2 Нина Владимировна Ивочкина запечатлена на фотографии выпускников 1983 г. (см.: рец. изд., стр. 439); в этом году отделение русской филологии Тартуского университета закончил ее сын, Роман Григорьев (ныне - профессор Факультета истории искусств Европейского университета, заведующий Отделением западноевропейской гравюры отдела западноевропейского искусства Государственного Эрмитажа).
} 
в глазах маститых лениградских ученых. Так научная известность 3. Г. своеобразным нимбом осенила и меня, а титул «ученик 3. Г. Минц» стал своего рода визитной карточкой.

Многие воспоминания, представленные в сборнике «Заре Григорьевне Минц посвящается...», пестрят самыми разными анекдотами, так или иначе связанными с 3. Г. Один из самых курьезных - в воспоминаниях М. Тарасенко «Лучше не было и не будет»: «Еще один раз она спасла всех посещавших спецкурс “История русской (не то советской - не помню) журналистики”. Это опять же был пятый курс, второй семестр, когда занятия уже почти не проводились. Спецкурс мы - а было нас человек десять - посещали хорошо, честно катались на него раз в неделю из Таллинна, но к концу весны возникла маленькая загвоздка: надо было сдавать зачет. А тут грядут защита дипломов, госэкзамен по научному коммунизму и - чего греха таить - прочая суета, включая пошив нарядов к выпускному. И время зачета не назначено. Зара Григорьевна произнесла что-то вроде “решите, когда хотите сдавать, и скажите мне”. И мы забыли. Или сделали вид, что забыли. А когда получили дипломы с вкладышами, увидели, что всем зачеты поставлены. Впрочем, никто в этом почти не сомневался <...>» (433).

К слову сказать, выбор точки зрения мемуариста (о чем и как писать) зависит не только от личности мемуариста, но и от личности, которая стала объектом воспоминания и осмысления. Личность 3. Г. в этом смысле представлялась чуть более приземленной, чем, скажем, личность Ю. М. Лотмана, явление которой у многих современников, особенно у студентов, вызывало просто священный трепет. Автор этих строк отнюдь не был исключением, хотя ему нередко доводилось бывать в доме Ю. М. Лотмана и 3. Г. Минц и он мог видеть Ю. М. Лотмана в неофициальной домашней обстановке. Помню, как однажды я с 3. Г. сидел в гостиной квартиры на ул. Бурденко - обсуждали мою дипломную работу. Вдруг появился Юрмих в совершенно домашнем облачении и спросил: «Заруша, не сделать ли вам кофе?» После полученного согласия Юрмих довольно быстро принес две чашки кофе и сливки. При этом он виновато-шутливо заметил о сливках: «Впрочем, форма не совсем соответствует 
содержанию...» (намекая этой репликой, что сливки, купленные в советском магазине, не всегда отличались приличным качеством). И, тем не менее, при виде Ю. М. Лотмана в домашней обстановке состояние «священного трепета» никак не исчезало. Не спасало даже благожелательное отношение самого Ю. М. Лотмана, который вовсе не стремился провоцировать в окружающих это трепетное состояние 3 . При общении же с 3. Г. такого «священного трепета» как-то не возникало.

Публикация рисунков и стихотворных экспромтов Ю. М. Лотмана в разделе «Из архива 3. Г. Минц и Ю. М. Лотмана» опять дает нам портрет 3. Г. не как серьезного академического ученого, а как персонажа домашней (семейной) мифологии. Так что у 3. Г. опять получается скорей биография-анекдот, а не биография-житие...

Другой интересный документ из того же раздела архивных публикаций - «Дневниковые записи 3. Г. Минц 1941-1944 годов». Документ представляет собой дневник 3. Г. за два коротких периода: с 10 мая по 14 августа 1941 г. и с 18 июля по 12 ноября 1944 г. Это сугубо житейский подростково-девический дневник. Не случайно М. Ю. Лотман свое послесловие к дневнику назвал так: «Дневники советской школьницы на фоне войны». На первый взгляд, эти дневниковые записи - не более, чем наивные подростковые наблюдения, да и основные темы вполне типичные для ленинградской школьницы той эпохи: уроки, учителя, экзамены, оценки, взаимоотношения с одноклассниками и т. п. Но порой вдруг сквозь школьную и пионерскую рутину прорывается нечто необычное. Вот запись от 15 мая 1941 г.:

«Уже скоро 12. На улице серо. И если долго смотреть в окно, то в глазах рябить начинает: сейчас белые ночи. Открыто окно. Радио

\footnotetext{
3 Даже много лет спустя, в феврале 1992 г., я по-прежнему не мог избавиться от этого чувства. Праздновался 70-летний юбилей Ю. М. Лотмана, в переполненном актовом зале Тартуского университета было устроено официальное торжество по этому случаю, приехала съемочная группа российского телевидения. Я уже был в статусе молодого ученого и старшего преподавателя Таллинского педагогического университета, вручал Ю. М. Лотману поздравительный адрес от имени кафедры русской литературы ТПУ. Помню, как я смущенно поздравил юбиляра с 70-летием. На что юбиляр шутливо ответил: «Я и сам не верю, что мне 70 лет».
} 
орет. <...> Сейчас я сделаю алгебру, а потом читать буду “Иудейскую войну”, если только папа спать не пошлет» (25). Скорей всего, речь идет о романе Леона Фейхтвангера «Иудейская война» (М., 1937). Однако заметим, что это - не самая ожидаемая книга в руках 13-летней советской школьницы.

Гораздо интереснее дневниковые записи 1944 г., где мы находим колоритные зарисовки советского быта и нравов конца войны. Но еще интереснее недатированные записи 1940-х годов (возможно, периода учебы в ЛГУ), в которых находим уже достаточно взрослые и разумные размышления о «диалектическом материализме»: «Нет ничего абсолютного. Так сказал еще Энгельс. Но он сам превратил учение о диалектике в абсолютную истину, в догму. Нам вбивают эту догму в голову и говорят, что она - единственно-верная. А, может быть, нет? Нам говорят, что в основе всего лежит вечное движение, вечный процесс рождения и умирания. На этом построена вся философия наша. Но, может это не так? Ведь признают же другие ученые основу мира метафизической. Нам говорят, что первооснова всего - материя. Но ведь и Гегель не был дураком, и он признавал абсолютную истину, исходя из чего-то! "Вдруг” все, совершенно все, чему нас учат - неверно?!» (122). Можно только удивиться тому, что советская студентка-комсомолка в середине 1940-х годов (!) рассуждает о «метафизической основе мира» и позволяет себе усомниться в верности догматов «диамата» и «истмата».

Здесь опять сделаю автобиографическое отступление. Записавшись в спецсеминар 3. Г. на 3-м курсе, я основательно стал изучать творчество поэта-символиста Вяч. Иванова. Поэтому пришлось штудировать многих философов и богословов, для которых «метафизическая основа мира» была аксиомой: Платона, Псевдо-Дионисия Ареопагита, блаженного Августина, Фр. Шеллинга, Вл. Соловьева и мн. др. В конце 1970-х сочинения христианских богословов и христианских философов если и не были опубликованы в СССР, то были вполне доступны для советского студента, поскольку дореволюционные издания всех этих «метафизиков» (или, как их называли советские учебники, «объективных идеалистов») обычно находились в спецхране 
(например, в отделе специального хранения научной библиотеки Тартуского университета). Доступ в спецхран был возможен для студентов при наличии официального отношения, в котором кафедра просила допустить студента имярека для работы над курсовой (или дипломной) работой по такой-то теме. Формально работники спецхрана имели право выдавать в читальном зале только те книги, которые прямо были связаны с темой курсовой или дипломной работы. Но в тартуском спецхране это правило выполнялось либерально, и студент фактически имел доступ к самым разным книгам (за исключением, конечно, совсем уж антисоветских, к коим философская и богословская литература не относилась). Поэтому для моего поколения переоценка догм марксизма-ленинизма происходила без особых препятствий и трудностей. Я уже не говорю о том, что в этом процессе общение с преподавателями, среди которых не было догматиков, сыграло дополнительную роль ${ }^{4}$.

Идеологический пресс 1940-х годов хорошо известен, тем более неожиданным оказывается тот факт, что студентка 3. Г. Минц с вполне советским пионерско-комсомольским идейным багажом так свободно подвергает сомнению догмы марксизма-ленинизма. Впрочем, тут надо сделать уточнение. Люди моего поколения тоже были перекормлены марксизмом-ленинизмом в разных его изводах, ведь изучение диамата и истмата было обязательным для всех студентов советских вузов. Разумеется, здравомыслящие студенты к этим предметам относились без особого энтузиазма, да и преподавались они, как правило, крайне скучно и догматически.

\footnotetext{
4 Из курса истмата, который нам читал проф. Р. Н. Блюм, запомнился такой курьезный эпизод. Как раз в 1978 г. были опубликованы мемуарные книги Л. И. Брежнева («Малая земля», «Возрождение», «Целина»). И, как полагалось в то время, в экзаменационные билеты по истмату был включен вопрос, посвященный этим пресловутым «мемуарам» генсека. На консультации кто-то из студентов спросил: «Будет ли Рэм Наумович Блюм требовать на экзамене знания этих текстов»? На что Рэм Наумович, ничтоже сумняшеся, ответил, что никого спрашивать по этому вопросу он не собирается. В итоге студенты не стали тратить время на это бесполезное чтиво, а Р. Н. Блюм, по всей вероятности, благополучно избежал идеологической проработки за столь пренебрежительное отношение к мемуарам генсека Л. И. Брежнева.
} 
Но за пеной догматизма и начетничества скрывалась и вполне нужная и полезная философская основа, почерпнутая из истории мировой философии (от античного диалектика Гераклита до Гегеля). Поэтому умные студенты отбрасывали из диамата и истмата ненужный идеологический хлам и усваивали основы диалектики и историзма (может быть, и не всегда это осознавая). Очень верно об этом написал М. Л. Гаспаров, когда разбирал философские истоки научного (структуралистского) метода Ю. М. Лотмана и отношение последнего к марксизму:

Методом марксизма был диалектический и исторический материализм. Материализм - это была аксиома «бытие определяет сознание», в том числе и носителя культуры - поэта и читателя. Историзм - это значило, что культура есть следствие социальноэкономических явлений своего времени. Диалектика - это значило, что развитие культуры, как и всего на свете, совершается в результате борьбы ее внутренних противоречий. А идеология учила иному. История уже кончилась, и начинается вечность идеального бесклассового общества, к которому все прошлое было лишь подступом. Все внутренние противоречия уже отыграли свою роль, и остались только внешние, между явлениями хорошими и плохими; нужно делить культурные явления на хорошие и плохие и стараться, чтобы хорошие были всесторонне хорошими и наоборот. Абсолютная истина достигнута, и владеющее ею сознание теперь само творит новое бытие. Идеология победившего марксизма решительно не совпадала с методом борющегося марксизма, но это тщательно скрывалось. Лотман относился к марксистскому методу серьезно, а к идеологии - так, как она того заслуживала. А известно, для догмы опаснее всего тот, кто относится к ней всерьез (Гаспаров 1996: 415-416).

В послесловии к публикации дневников 3. Г. Минц М. Лотман оговаривается: «После долгих колебаний и совещаний с членами семьи я дал согласие на публикацию дневниковых записей моей матери. Они не предназначались для постороннего чтения, менее того - для печати» (131). Соображения эти верны лишь отчасти. Ведь дневники любого человека (за редким исключением) не 
предназначены для постороннего чтения, да и для печати тоже. Что не мешает им быть опубликованными и стать интересным и полезным биографическим источником. Что может смутить читателя в этих дневнике 3. Г.? Да по сути дела - ничего (разве что какие-то глубоко личные и сокровенные мысли, но их в дневнике 3. Г., как кажется, нет). А сам дневник содержит немало интересных и познавательных зарисовок, которые показывают не только быт и нравы эпохи, но и личность самого автора дневника. Между прочим, даже в этих подростково-девических дневниковых записях уже отчетливо проявился стиль 3. Г.

Научное наследие 3. Г., без сомнения, еще ждет своего исследователя. Этот же сборник по преимуществу воссоздает тот живой образ Человека и Учителя, который навсегда останется в памяти всех, кому посчастливилось встречаться и общаться с этим удивительным человеком - 3. Г. Минц.

\section{БИБЛИОГРАФИЯ}

Гаспаров М. Л. 1996. Лотман и марксизм. - Лотман Ю. М. Внутри мыслящих миров: Человек - текст - семиосфера - история. М.: Языки русской культуры. С. 415-426.

Лотман Ю. М. 1986. Литературная биография в историко-культурном контексте (К типологическому соотношению текста и личности автора). - Литература и публицистика: Проблемы взаимодействия. Труды по русской и славянской филологии. Тарту: [Tartu Riiklik Ülikool]. C. 106-121 (Ученые записки Тартуского государственного университета. Вып. 683).

\section{REFERENCES}

Gasparov, M. L. “Lotman i marksizm.” In Lotman, Iu. M. Vnutri mysliashchikh mirov: Chelovek - tekst - semiosfera - istoriia, 415-26. Moscow: Iazyki russkoi kul'tury, 1996.

Lotman, Iu. M. "Literaturnaia biografiia v istoriko-kul'turnom kontekste (K tipologicheskomu sootnosheniiu teksta i lichnosti avtora)." Literatura i publitsistika: Problemy vzaimodeistviia. Trudy po russkoi i slavianskoi filologii, 106-21. Tartu: [Tartu Riiklik Ülikool], 1986. 